\title{
The Adoption and Implementation of RFID: A Literature Survey
}

\author{
Mohd Kamir Yusof \\ Universiti Sultan Zainal Abidin, Malaysia \\ mohdkamir@unisza.edu.my \\ Md Yazid Saman \\ Universiti Malaysia Terengganu, Malaysia \\ madyaz@gmail.com
}

\begin{abstract}
Background. Radio Frequency Identification (RFID) offers tracking capability to locate equipment, supplies and people in real time, and provides efficient and accurate access to library transactions such as book search, borrow, book return, etc. However, the adoption of RFID in libraries lags behind earlier expectations. Objectives. A formal innovation-decision framework is used to analyze the literature on the use of RFID in libraries. The purpose is to identify common applications, potential benefits, barriers and critical success factors. This paper seeks to offer quick assessment of RFID in libraries and provide guidance for researchers and practitioners in adopting RFID in libraries.

Results. Many earlier adopters in libraries found RFID to be functional and useful in such areas as asset tracking and item identification. Major barriers to adoption include technological limitations, interference concerns, prohibitive costs, lack of global standards and privacy concerns. A better designed RFID system available at a low cost and that addresses privacy issues is needed to increase the adoption of RFID in libraries.
\end{abstract}

\section{INTRODUCTION}

RFID is being used for a wide variety of applications ranging from building access control proximity cards to supply chain tracking, toll collection, vehicle parking access control, retail stock management, ski lift access, library books tracking, theft prevention, vehicle immobilizer systems, and railway rolling stock identification and movement tracking. This paper reviews the literature on the use of RFID in library management and service through an innovation decision framework. We provide a brief introduction to the RFID technology, current challenges faced by libraries, and how the use of RFID technology can address these challenges. Next, we analyze the specifics of RFID technology in different areas of library management and services before examining the potential benefits of RFID, and identifying barriers to its acceptance. Finally, we propose a critical success factor framework for RFID implementation based on the publications reviewed and provide guidance for librarians.

RFID technology is widely used in libraries. However, the number of published papers on the use of RFID technology in libraries lags behind the number of papers on its use in supply chain. Mehrjerdi (2011) reviewed the implementation of RFID technology in libraries, and suggested developing RFID technology for library search. RFID has revolutionized library management and practices. According to the Singapore National Library Board, most 
libraries in Singapore are aggressively using RFID technology, resulting in 9 million books, videos and DVDs being embedded with antitheft chips and allowing for self-checkout. In Australia, Brisbane City Council's libraries have used an RFID system at their Wynnum branch since June 2001 (Cadoo, 2004). Successful implementation and use of RFID technology is also evident in the United States, United Kingdom, Canada, South Korea and New Zealand.

\section{OVERVIEW OF THE RFID TECHNOLOGY}

RFID is one of the Automatic Identification and Data Capture (AIDC) technologies. The purpose of such technologies is to identify objects, automatically collect data about the objects and update the data into a computer system without human intervention (Potdar, Wu \& Chang, 2010). RFID is an electronic information technology that utilizes wireless radio waves to transmit, identify, trace, sequence and confirm various objects (Liu \& Chen, 2009; Roberts, 2006). It can be characterized as an electromagnetic proximity identification and data transaction system (Roberts, 2006). Two components in RFID are the tag and reader. RIFD tags are used to tag objects or assets, and an RFID reader gathers the tag information. RFID technology is a replacement for barcode technology in terms of non-optical proximity communication, information density and two-way communication. Compared to barcode technology, RFID technology possesses powerful properties which include being waterproof, having a magnetic scratch-resistant protection layer, being heat resistant, being long lasting, transmitting data transmission over long and short distances, data encryption, and relatively large memory capacity (Bi, Cao \& Sheng, 2011). RFID technology is also more powerful than other AIDC technologies such as cameras, magnetic cards and identity card because of its data read and write functions, easy miniaturization and diversification of the shape, environmental resistance, reusability, data penetration, data memory capacity, system security and data security.

RFID uses several common methods of identification, but the most common method is the association of the RFID tag unique identifier with an object or person. The basic concepts in RFID diagram typically comprise the following (Ramanathan, Ramanathan, Wan \& Ko, 2014):

1. An RFID device (tag)

2. A tag reader with an antenna and transceiver

3. A host system or connection to an enterprise system.

RFID devices can be divided into two categories:

1. RFID devices with power supply (battery)

2. RFID devices without power supply.

RFID devices with power supply are known as transponders (transmitter/responder). Sometimes they are called "active tags.” RFID devices without power supply are known simply as "tags," or "passive tags.” Active tags are more expensive than passive tags. Passive tags have an unlimited life and are lighter, smaller and cheaper. Tags can incorporate readonly memory (ROM), volatile read/write random access memory (RAM), or write once/read many memory (WORM). An antenna serves as a conduit between RFID tags and the RFID reader. RFID antennas emit radio waves that activate RFID tags as they pass through the activation field. The antenna sends or receives information from the RFID reader after a tag is activated. 
Table 1. Journals and conferences that yielded relevant articles on RFID in library and information service

\begin{tabular}{l|c|c}
\hline Journal/Conference/Book Chapter & Number & $\mathbf{\%}$ \\
\hline Others & 32 & 44 \\
IEEE Explore & 10 & 14 \\
Library Hi Tech & 6 & 8 \\
The Electronic Library & 5 & 7 \\
SpringerLink & 3 & 4 \\
Journal of Academic Librarianship & 2 & 3 \\
Journal of Access Services & 2 & 3 \\
The Australian Library Journal & 2 & 3 \\
American Society of Mechanical Engineers Digital Library & 1 & 1 \\
Journal of Interlibrary Loan, Document Delivery and Electronic Reserve & 1 & 1 \\
Journal of Electronic Resources in Medical Libraries & 1 & 1 \\
International Journal of Distributed Systems and Technologies & 1 & 1 \\
Australian Academic \& Research Libraries & 1 & 1 \\
International Journal of Information Management & 1 & 1 \\
Journal of Enterprise Information Management & 1 & 1 \\
New World Library & 1 & 1 \\
Library and Information Science Research & 1 & 1 \\
International Journal of Multimedia and Ubiquitous Engineering & 1 & 1 \\
\hline Total & 71 & 100 \\
\hline
\end{tabular}

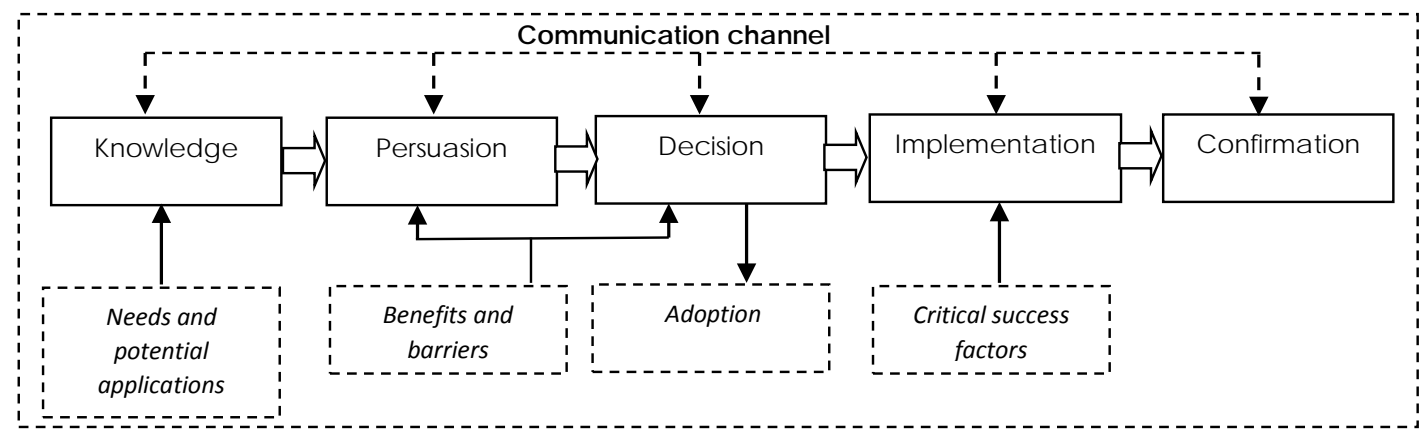

Figure.1. A reviewing framework for literature categorization and analysis

\section{STUDY FRAMEWORK}

This literature review was carried out in three phases: literature identification, categorization and analysis.

Phase 1: Literature identification and collection: The literature search was conducted in indexing and fulltext databases, including Emerald, IEEE Explore, Science Direct, Springer Link, Taylor \& Francis Online and Association for Computing Machinery Digital Library. The search was performed in early January 2015 and repeated at the end of June 2015, employing the following keywords and their combinations in the title, keyword and abstract fields: RFID, information science, library system and library management. Journal articles, 


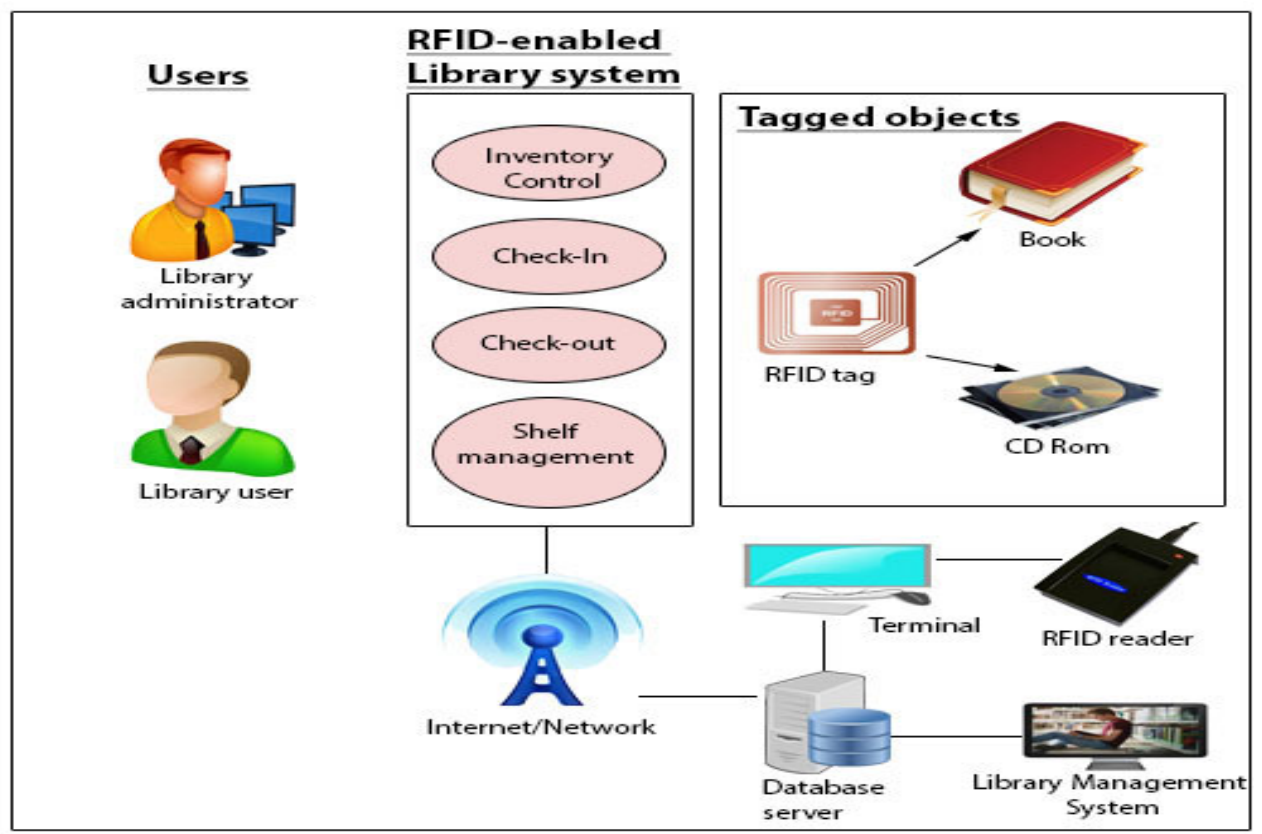

Figure 2. RFID-enabled library system

conference papers, and book chapters addressing the use of RFID in library and information services were identified.

As the literature review was limited to peer-reviewed publications, technical reports and news were excluded. More than 130 articles were identified, and 72 of them were reviewed based on their relevance to this study. Table 1 summarizes the major publication venues in descending order of the number of publications. They span diverse fields including digital libraries, medical libraries, research libraries, information management, multimedia, engineering and information science. Article topics include prototypes, case studies, pilot studies, and systems already in use. Mendeley was used as a bibliography management tool to manage the references and citations (Mendeley, 2010).

Phase 2: Literature categorization: In this phase, the innovation decision process proposed by Sahin (2006) was used as a formal conceptual framework to categorize the articles. Figure 1 outlines the innovation decision process. Five stages are involved in this process: knowledge, persuasion, decision, implementation and confirmation. Organizations learn about the technology, their current needs and potential application areas in the knowledge stage. In the persuasion stage, a favorable or unfavorable attitude towards RFID technology is formed. The most important activities in this stage are evaluating and balancing the benefits of and barriers to RFID technology, in order to make a decision for adoption. Finally, RFID projects are deployed and put into use at the implementation stage. Case studies, site surveys, and interviews are included in the literature review since they focus on RFID implementation in practice.

Phase 3: Literature analysis: In the last phase, we analyzed the publications in different categories and have presented our results according to the review framework. We discuss our findings in the following sections: needs and potential applications, benefits and barriers that can promote or impede the adoption of RFID technology, and critical success factors. 
Table 2. RFID application in various areas in information science

\begin{tabular}{|c|c|c|c|}
\hline Application & Sub-area & $\%$ & References \\
\hline \multirow[t]{4}{*}{ Tracking } & Track book location & 7.58 & $\begin{array}{l}\text { Curran \& Porter, 2007; Kapoor, Dwivedi, } \\
\text { Piercy \& Lal, 2014; Cunningham, 2010; Li, } \\
\text { 2013; Rajasekar, Dhanakar, Pandian \& } \\
\text { Malliga, } 2008\end{array}$ \\
\hline & Track DVDs location & 9.10 & $\begin{array}{l}\text { Markakis, Samaras, Polycarpou \& Sahalos, } \\
\text { 2013; Dhanalakshmi \& Mamatha, 2009; } \\
\text { Schneider, } 2003\end{array}$ \\
\hline & Track Video location & 4.55 & $\begin{array}{l}\text { Zhang \& Shi, 2011; Kapoor, Dwivedi, Piercy \& } \\
\text { Lal, 2014; Butters, } 2008\end{array}$ \\
\hline & Keep track user history & 6.10 & $\begin{array}{l}\text { Mohideen, Muhamad, Ghadzali \& Mohd } \\
\text { Arshad, } 2012\end{array}$ \\
\hline \multirow[t]{4}{*}{$\begin{array}{l}\text { Shelf } \\
\text { management } \\
\text { of resources }\end{array}$} & Book stocktaking & 7.58 & $\begin{array}{l}\text { Caldwell-stone, 2010; Chelliah, Sood \& } \\
\text { Scholfield, n.d.; Coyle, 2005; Jain \& Krishna, } \\
2014\end{array}$ \\
\hline & $\begin{array}{l}\text { Book arrangement, book } \\
\text { movement }\end{array}$ & 4.55 & $\begin{array}{l}\text { Evans \& Moore, 2013; Chelliah, Sood \& } \\
\text { Scholfield, n.d.; Makori, } 2013\end{array}$ \\
\hline & $\begin{array}{l}\text { Placing of new book on } \\
\text { shelf }\end{array}$ & 4.55 & $\begin{array}{l}\text { Evans \& Moore, 2013; Howard \& Anderson, } \\
\text { 2005; Makori, } 2013\end{array}$ \\
\hline & Inventory control & 7.58 & $\begin{array}{l}\text { Yu, 2008; Butters, 2008; Howard \& Anderson, } \\
\text { 2005; Singh \& Midha, } 2008\end{array}$ \\
\hline \multirow[t]{5}{*}{$\begin{array}{l}\text { Self-service } \\
\text { and self- } \\
\text { sufficiency }\end{array}$} & $\begin{array}{l}\text { Borrowing and returning } \\
\text { book }\end{array}$ & 9.10 & $\begin{array}{l}\text { Cadoo, 2004; Bansode \& Desale, 2009; Evans } \\
\text { \& Moore, 2013; Abdou, 2012; Boss, 2003; } \\
\text { Power, } 2005\end{array}$ \\
\hline & Check-in \& check-out & 10.61 & $\begin{array}{l}\text { Ramanathan, Ramanathan, Wan \& Ko, 2014; } \\
\text { Sahin, 2006; Sumi \& Kumar, 2007; Satpathy \& } \\
\text { Mathew, 2006; Shahid, 2005; Power, 2005; } \\
\text { Coyle, 2005; Yu, } 2007\end{array}$ \\
\hline & Book drop & 4.55 & $\begin{array}{l}\text { Minami, 2006; Shahid, 2005; Engel, 2006; } \\
\text { Power, } 2005\end{array}$ \\
\hline & Verification & 3.03 & $\begin{array}{l}\text { Satpathy \& Mathew, 2006; Chelliah, Sood \& } \\
\text { Scholfield, n.d. }\end{array}$ \\
\hline & Self service & 3.03 & $\begin{array}{l}\text { Madhusudhan, 2010; Library Book / Media } \\
\text { Management and RFID Tracking, n.d. }\end{array}$ \\
\hline \multirow[t]{2}{*}{ Security } & $\begin{array}{l}\text { Security detection } \\
\text { system }\end{array}$ & 12.12 & $\begin{array}{l}\text { Bi, Cao \& Sheng, 2011; Mendeley, 2010; } \\
\text { Satpathy \& Mathew, 2006; Rajasekar, } \\
\text { Dhanakar, Pandian \& Malliga, 2008; Evans } \\
\text { \& Moore, 2013; Coyle, 2005; Mamdapur \& } \\
\text { Rajgoli, } 2011\end{array}$ \\
\hline & Control theft & 6.10 & $\begin{array}{l}\text { Rajasekar, Dhanakar, Pandian \& Malliga, 2008; } \\
\text { Evans \& Moore, 2013; Blansit, 2010; Singh \& } \\
\text { Mahajan, } 2014\end{array}$ \\
\hline
\end{tabular}


Table 3. Selected RFID systems reported in the literature

\begin{tabular}{|c|c|c|}
\hline System & Adopter & Function \\
\hline $\begin{array}{l}\text { Jayakar Library } \\
\text { System (Bansode \& } \\
\text { Desale, 2009) }\end{array}$ & $\begin{array}{l}\text { University of Pune } \\
\text { Library }\end{array}$ & $\begin{array}{l}\text { RFID technology supports quick, accurate and timely } \\
\text { information to users; quick circulation of books with no } \\
\text { queues in front of the circulation counter; fast tracking and } \\
\text { shelving of books. }\end{array}$ \\
\hline $\begin{array}{l}\text { LIBSYS in New } \\
\text { Delhi, India } \\
\text { (Madhusudhan, 2010) }\end{array}$ & $\begin{array}{l}\text { Indian Law Institute } \\
\text { Library and National } \\
\text { Social Science } \\
\text { Documentation Centre } \\
\text { Library, New Delhi }\end{array}$ & $\begin{array}{l}\text { RFID supports self-service reservations, enquiries and } \\
\text { integration with management information and anti-virus } \\
\text { protection. Supports return status and print receipt showing } \\
\text { that books are returned. }\end{array}$ \\
\hline $\begin{array}{l}\text { RFID based System } \\
\text { for Library } \\
\text { Management } \\
\text { (Fujisaki, 2015) }\end{array}$ & $\begin{array}{l}\text { Kyushu University } \\
\text { Library, Japan }\end{array}$ & $\begin{array}{l}\text { Supports efficient book rental and return, collection } \\
\text { inventory, book search and access control. }\end{array}$ \\
\hline $\begin{array}{l}\text { RFID in Australian } \\
\text { Academic Library } \\
\text { (Butters, 2008) }\end{array}$ & $\begin{array}{l}\text { Australian Academic } \\
\text { Libraries }\end{array}$ & $\begin{array}{l}\text { Supports collection management activities including } \\
\text { inventory of materials, shelf ordering, and weeding. }\end{array}$ \\
\hline $\begin{array}{l}\text { RFID system for } \\
\text { library (Chelliah, } \\
\text { Sood \& Scholfield, } \\
\text { n.d.) }\end{array}$ & $\begin{array}{l}\text { University of } \\
\text { Technology Sydney, } \\
\text { Australian }\end{array}$ & $\begin{array}{l}\text { Supports automatic library retrieval system, monitoring } \\
\text { user transactions (for example, book borrowing, book } \\
\text { return, etc.), faster self-checkout, efficient inventory } \\
\text { records and management. } \\
\text { Supports fast book tracking and book searching by unique } \\
\text { ID. }\end{array}$ \\
\hline $\begin{array}{l}\text { Library Management } \\
\text { System Rajasekar, } \\
\text { Dhanakar, Pandian \& } \\
\text { Malliga, 2008) }\end{array}$ & $\begin{array}{l}\text { Anna University } \\
\text { Library }\end{array}$ & $\begin{array}{l}\text { Supports fast book tracking, fast charge and discharge, } \\
\text { inventory, and materials handling. } \\
\text { Function in shelf management includes search for } \\
\text { individual books requested, inventory check of the whole } \\
\text { library stock, and search for books which are misshelved. }\end{array}$ \\
\hline $\begin{array}{l}\text { RFID based Library } \\
\text { Management System } \\
\text { ( Ansari \& Khatri, } \\
\text { 2011) }\end{array}$ & $\begin{array}{l}\text { Library Management } \\
\text { System }\end{array}$ & $\begin{array}{l}\text { Supports borrowing of more than one book at one time } \\
\text { easily and efficiently. Users are able to find the physical } \\
\text { location of a book. The process of issuing, re-issuing and } \\
\text { returning are faster. }\end{array}$ \\
\hline $\begin{array}{l}\text { RFID Assistance } \\
\text { System (Satpathy \& } \\
\text { Mathew, 2006) }\end{array}$ & Public Libraries & $\begin{array}{l}\text { Supports book search function in the library database, with } \\
\text { book location. Book management, book organization, } \\
\text { security and database maintenance are more efficient. }\end{array}$ \\
\hline $\begin{array}{l}\text { RFID systems } \\
\text { (Dwivedi, Kaur, } \\
\text { Williams \& } \\
\text { Williams, 2013) }\end{array}$ & Libraries & $\begin{array}{l}\text { Supports tagging of new items, shelving, issuing items to } \\
\text { customers, alerting staff to late returns, re-shelving after } \\
\text { return, inventory management, and protecting items from } \\
\text { theft. }\end{array}$ \\
\hline $\begin{array}{l}\text { RFID Based Library } \\
\text { Management System } \\
\text { (Vimalraj \& } \\
\text { Sameera, 2015) }\end{array}$ & Libraries & $\begin{array}{l}\text { Supports quick and easy book search, sending of reminders } \\
\text { to users of book due dates, book drop and return chutes for } \\
\text { returning library materials. RFID enabled user cards } \\
\text { support easy user identification. }\end{array}$ \\
\hline $\begin{array}{l}\text { RFID applications } \\
\text { (Makori, 2013) }\end{array}$ & $\begin{array}{l}\text { Kenyan University } \\
\text { Libraries }\end{array}$ & Supports information services and activities. \\
\hline
\end{tabular}




\section{NEEDS AND POTENTIAL APPLICATIONS}

In this paper, RFID functionality is divided into four application categories: tracking, shelf management of resources, self-service and self-sufficiency, and security. Table 2 lists the number of articles reviewed in each category and their sub-areas. Several papers described more than one application and are listed in more than one category.

Table 3 summarizes common library applications reported in the literature. In the library, RFID applications need to be integrated with the Library Management System (LMS). The LMS is the management information system used to manage, record, update and maintain the library data on book, articles, etc. The purpose of implementing RFID in a library is to manage and handle information services and activities in libraries such as checkin, check-out, inventory control and self-management. Figure 2 presents a diagram that summarizes the implementation of RFID technology in libraries. Figure 2 indicates that potential users are divided into two categories: library administration and library users. The tasks of a library administrator include recording new items, updating items, deleting items and viewing transactions. The tasks of library users include book borrowing, book return, book search and viewing transaction records. These users can benefit from the implementation of RFID technology in the library.

\section{BENEFITS OF ADOPTING RFID TECHNOLOGY}

The perceived benefits of adopting RFID technology in libraries are summarized in Table 4.

\section{Tracking/Item Identification}

RFID was already used in libraries in the late 1990s for tracking purposes (Bansode \& Desale, 2009). RFID replaced the barcode technology for tracking book items in libraries. Implementation of an RFID system offers speed in book finding ; Zhang \& Shi, 2011), accurate book positioning search (Feng, 2010), inventory tracking (Suda \& Rani, 2013), and a more efficient way to track (Sumi \& Kumar, 2007; Narayanan, Singh \& Somasekharan, 2005; Ansari \& Khatri, 2011), locate and manage library materials (Kotecha, 2008). RFID is designed to track library items without requiring line of sight (Mehrjerdi, 2011; Yu, 2008; Kapoor, Dwivedi, Piercy \& Lal, 2014; Satpathy \& Mathew, 2006). An RFID system can also track user history of library transactions (Kern, 2004). Tracking library items such as books, DVDs and videos is one of the most widely used applications in libraries (Satoglu, Ustundag \& Kilinc, 2013). In an RFID system, data for each library item is stored in an RFID tag. In the United States, each library item is usually identified by a unique 14-digit number (Viziteu, Florean, Moraru \& Pintea, 2012). An RFID reader will read the data from the RFID tag and transmit the data in radio wave to the library system. In China, Jimie University Library, Chengyi College Library, Shenzhen Library, Xiamen Library, Hangzhou Library and the National Library use Ultra High Frequency (UHF) technology to store book information (Huang, 2012). The advantage is efficiency (Markakis, Samaras, Polycarpou \& Sahalos 2013), speed and accuracy (Dhanalakshmi \& Mamatha, 2009). Processing of books on the shelf and stocktaking is more efficient (Curran \& Porter, 2007).

\section{Shelf Management of Resources}

Shelf management of resources in a library is an issue that must be handled by the implementation of suitable technology. Shelf management involving book stocktaking (Cunningham, 2010), arranging books, putting new books on the shelf, book moving and 
Table 4. Summary of perceived benefits of RFID in libraries

\begin{tabular}{|c|c|}
\hline Benefits & Findings (empirical studies, questionnaire surveys and opinions) \\
\hline Fast tracking & $\begin{array}{l}\text { Fast book finding (Curran \& Porter, 2007; Zhang \& Shi, 2011). } \\
\text { Efficient book scanning (Markakis, Samaras, Polycarpou \& Sahalos, } \\
\text { 2013). } \\
\text { Inventory tracking (Suda \& Rani, 2013). } \\
\text { Efficient way to track, locate and manage library materials (Kotecha, } \\
\text { 2008). } \\
\text { The perfect tracker (Sumi \& Kumar, 2007). } \\
\text { Books and accurate positioning search (Feng, 2010). }\end{array}$ \\
\hline $\begin{array}{l}\text { Efficient shelf } \\
\text { management service }\end{array}$ & $\begin{array}{l}\text { Easy to manage huge number of books (Mohideen, Muhamad, Ghadzali } \\
\text { \& Mohd Arshad,2012). } \\
\text { Efficient management of library collection (Butters, 2008). } \\
\text { High speed inventory (Cadoo, 2004; Rajasekar, Dhanakar, Pandian \& } \\
\text { Malliga, 2008). } \\
\text { Efficient inventory management (Schneider, 2003). } \\
\text { Automated materials handling (Narayanan, Singh \& Somasekharan, } \\
\text { 2005). }\end{array}$ \\
\hline Efficient shelf service & $\begin{array}{l}\text { Supports reservation, enquiries, and integration with management } \\
\text { information and anti-virus protection (Madhusudhan, 2010). } \\
\text { Saves time for circulation counter in the following processes - check-in, } \\
\text { check-out and renewal (Bansode \& Desale, 2009; Mamdapur \& Rajgoli, } \\
\text { 2011). } \\
\text { Faster circulation (Mehrjerdi, 2011; Minami, 2006; Library Book/Media } \\
\text { Management and RFID Tracking, n.d.). } \\
\text { Self-service for book borrowing and book returning becomes easier and } \\
\text { simpler (Bi, Cao \& Sheng, 2011; Howard \& Anderson, 2005). } \\
\text { Speed up the borrowing and returning procedures (Shahid, 2005; Ansari } \\
\text { \& Khatri, 2011). }\end{array}$ \\
\hline $\begin{array}{l}\text { Improved security } \\
\text { levels }\end{array}$ & $\begin{array}{l}\text { Increased security of items for loan (Madhusudhan, 2010). } \\
\text { Theft detection functionality (Bansode \& Desale, 2009; Abdou, 2012). } \\
\text { Prevents thefts with security gates (Satoglu, Ustundag \& Kilinc, 2013; } \\
\text { Singh \& Midha, 2008). } \\
\text { Enhances security of library collection (Singh \& Mahajan, 2014). } \\
\text { Efficiency in security (Howard \& Anderson, 2005). } \\
\text { Supports effective library detection system (Rafiq, 2004). }\end{array}$ \\
\hline
\end{tabular}

book shelving are obviously related (Li, 2013; Huang, 2012). With RFID, handheld scanners and a shelf management software that generates inventory reports are used to solve the problem (Singh \& Midha, 2008; Mohideen, Muhamad, Ghadzali \& Mohd Arshad, 2012). RFID technology provides functionality to manage a library collection efficiently (Butters, 2008), including high speed inventory (Cadoo, 2004; Rajasekar, Dhanakar, Pandian \& Malliga, 2008), efficient inventory management (Schneider, 2003), automated materials handling (Narayanan \& Somasekharan, 2005), along with the ability to scan books on the shelves without taking them out or removing them. An important function in libraries with large collections is periodic stock taking(Satoglu, Ustundag \& Kilinic, 2013). By 
implementing RFID, inventory management becomes more efficient, and cost effective (Howard \& Anderson, 2005).

\section{Self-Service and Self-Sufficiency}

An RFID system makes it easier and faster for users to serve themselves (self-service) and be self-sufficient in terms of access to information resources (Chelliah, Sood \& Scholfield, n.d.; Makori, 2013). RFID systems support self-service in terms of reservations, enquiries, and integration with management and anti-virus protection (Madhusudhan, 2010). An RFID system in a library usually involves subsystems for book borrowing (Rajasekar, Dhanakar, Pandian \& Malliga, 2008), returning, smart inventory, intelligent query system and security detection system ( $\mathrm{Li}, 2013)$. Most public libraries and university libraries in China have planned for RFID system applications since 2006 (Bi, Cao \& Sheng, 2011). University libraries in Egypt, with a large user population, have been successful in using RFID technology in collection management and the checking out of materials (Abdou, 2012). RFID systems support easy borrowing and returning of books (Dhanalakshmi \& Mamatha, 2009; Boss, 2003). Check-in and check-out using an RFID system is also faster (Power, 2005; Shahid, 2005; Ansari \& Khatri, 2011). To achieve greater self-service function (aiming for 98\%), RFID is a good alternative to the traditional staff circulation desk (Engel, 2006). Another function of the RFID system is the self-return book drop (Singh \& Midha, 2008).

\section{Security}

An RFID system provides a security mechanism to prevent theft of library resources (Coyle, 2005). An RFID tag is used as a special "security bit" that can be switched from "checked-in" to "check-out". The exit gates in the library read each tag when the user leaves the library and sounds an alarm if the bit is not "checked out". The function of check-in resets the bit. RFID provides efficient operation processing where each user can simultaneously process checkin/out, verification, and entrance guard control with an RFID reader equipment (Yu, 2007). The amount of time required to perform circulation operations can be reduced through RFID (Bansode \& Desale, 2009; Mehrjerdi, 2011; Minami, 2006; "Library Book/Media Management and RFID Tracking”, n.d.; Mamdapur \& Rajgoli, 2011). The circulation operations become more efficient (Power, 2005), easy and simple (Bi, Cao \& Sheng, 2011; Howard \& Anderson, 2005).

RFID has high-security technology which can be used in a library as an anti-theft system (Butters, 2008; Chelliah, Sood \& Scholfield, n.d.; Coyle, 2005). There is greater security of items for loan when using RFID technology (Madhusudhan, 2010). RFID supports theft detection functionality (Abdou, 2012; Bansode \& Desale, 2009), efficiency in security (Howard \& Anderson, 2005) and effective tracking for library items (Rafiq, 2004). RFID has been used in theft detection and item tracking for over 30 years and was first used in libraries in the late 1990s (Bansode \& Desale, 2009). RFID is better for collection management and security (Yu, 2007). In the United States, RFID library systems use $13.56 \mathrm{MHz}$ for security gates (Blansit, 2010). RFID readers are mounted at the exit gates of the library. Sensors are designed to detect and read information from RFID tags. As the user passes through the exit gate, the system reads the tags in the books in the user's arm or bag and cross checks with the library database, ensuring that the items have been checked out (Dhanalakshmi \& Mamatha, 2009). The implementation of RFID technology can help prevent theft during the check-out 
and after the check-in of items (Satoglu, Ustundag \& Kilinc, 2013; Singh \& Midha, 2008). RFID technology promises to provide better control of theft (Singh \& Mahajan, 2014).

RFID technology is suitable for use in the library because RFID tags can be re-used. The cost of RFID tags can be reduced because library books/items are taken out and returned many times (Fennani \& Hamam, 2008).

Transactions in university libraries have become faster with RFID systems. A few university libraries in Africa such as the University of South Africa and the American University in Egypt reported success in the use of an RFID system (Makori, 2013). The amount of time required to perform circulation operations for charging and discharging is reduced (Madhusudhan, 2010). In fact, information can be read from RFID tags much faster in comparison to barcodes. Libraries used to scan barcodes one by one which was timeconsuming (Shahid, 2005). With an RFID system, users can simultaneously process checkout/in, verification and entrance guard control (Yu, 2007). An RFID system is able to read several items in a stack at the same time (Condos \& Ginther, 2011). The check-in and checkout process does not take more than one minute using an RFID system (Madhusudhan, 2010). Self-discharging service saves time for both staff and customers at service points, while increasing satisfaction (Shahid, 2005).

RFID is able to improve security and inventory control in comparison to barcode technology because RFID tags can be read even when they are not directly within the scanner's line of sight (Chelliah, Sood \& Scholfield, n.d.). RFID provides added security and authentication (Curran \& Porter, 2007; Jain \& Krishna, 2014). Electronic Article Surveillance (EAS) is used to protect against theft. EAS is easy to use (Sumi \& Kumar, 2007). Library staff can place the item on the reader and click on the view function to display the information stored inside the tag and the status of EAS. Auto arm/disarm will automatically arm/disarm material that is within the reader range. The rationale for using RFID for security purposes is not because it is particularly strong in this area, but because it is not inferior to other security technologies (Coyle, 2005).

In summary, the benefits of using RFID technology in libraries have been stated from a variety of sources. These benefits actually impact all parties involved in library services.

\section{BARRIERS TO ADOPTING RFID TECHNOLOGY}

RFID adoption in library and information service presents a host of challenges, including technological, economic, social and other issues. Table 5 summarizes the barriers identified in the literature.

\section{Policy Issues}

The lack of ICT policies (Makori, 2013) to adopt and embrace modern technologies into mainstream information services can impede the adoption and development of RFID applications in university libraries. Often, the policies to guide university libraries with regard to adopting technological solutions are not followed. The standardization of operations also varies across countries (Singh \& Mahajan, 2014).

\section{Technical Issues}

Technical issues include abnormal signals resulting from environmental differences, higher energy of electromagnetic waves in transient transmission while driving tags by RFID readers, consistency between different suppliers of RFID readers and tags ( $\mathrm{Yu}, 2008)$. 


\section{Table 5. Barriers to RFID adoption in Libraries}

\begin{tabular}{|c|c|}
\hline Barriers & Findings (Experiments, case, study, interview) \\
\hline Ineffectiveness & $\begin{array}{l}\text { Abnormal signals resulted from the environment is different because of depends } \\
\text { on energy usage of electromagnetic wave in transient transmission while driving } \\
\text { tags by RFID readers (Yu, 2008). } \\
\text { Getting adequate hardware, the compatibility between tags and readers is } \\
\text { important, along with the required frequency and other parameters (Addepalli \& } \\
\text { Addepalli, 2014). }\end{array}$ \\
\hline Interference & $\begin{array}{l}\text { Interference with metal or fog, the distance between reader and tag, and the } \\
\text { antenna direction are factors that may lead to a loss of signal detection (Yu, } \\
\text { 2007). } \\
\text { The possibility of nearby devices interfering with the security gates; the } \\
\text { transmission of the security gates may also interfere with other nearby devices } \\
\text { (Blansit, 2010). } \\
\text { Reader collision occurs because the signal from one reader can interfere with the } \\
\text { signal from another when coverage overlaps (Singh \& Midha, 2008). }\end{array}$ \\
\hline Standardization & $\begin{array}{l}\text { Aligning university libraries with RFID systems (Makori, 2013). } \\
\text { Operation standards and regulations are different for each country (Singh \& } \\
\text { Mahajan, 2014). }\end{array}$ \\
\hline Cost & $\begin{array}{l}\text { A library size of 100,000 items has to invest about USD 150,000 in total for the } \\
\text { initial budget (Kern, 2004). } \\
\text { The cost of developing an RFID system in a library is high (Madhusudhan, } \\
\text { 2010), (Bahri \& Ibrahim, 2013). }\end{array}$ \\
\hline Privacy \& Security & $\begin{array}{l}\text { Privacy is a major concern because RFID readers can detect all user activities, } \\
\text { such as reading, browsing, and other actions (Mehrjerdi, 2011). } \\
\text { Privacy issues for users and staff (Power, 2005). }\end{array}$ \\
\hline Other barriers & $\begin{array}{l}\text { Lack of technology experts (Bansode \& Desale, 2009). } \\
\text { Integration with current process (Chelliah, Sood \& Scholfield, n.d.). } \\
\text { Difficulty integrating RFID with existing library automation systems (Bi, Cao \& } \\
\text { Sheng, 2011). }\end{array}$ \\
\hline
\end{tabular}

Compatibility between tags and readers is important, along with the required frequency and other parameters (Addepalli \& Addepalli, 2014). In addition, the lack of standardization of specifications relating to RFID equipment, including chip standards, communication transmission agreements, and programming interface poses further challenges.

Another issue is interference. Accuracy in the transmission process is influenced by real-time efficiency of the application. One problem is the detection of a signal. This problem occurs because of interference from metal or fog, the distance between the reader and the tag, and the antenna direction (Yu, 2007). A second problem is the possibility of nearby devices interfering with security gates, the transmission of the security gates may also interfere with other nearby devices (Blansit, 2010). A third problem is reader collision (Singh \& Midha, 2008). Reader collision occurs because the signal from one reader can interfere with the 
signal from another where coverage overlaps. Once this happens, it is likely that the RFID reader is transmitting incorrect information.

The lack of technology experts (Bansode \& Desale, 2009), integration with current systems or processes (Chelliah, Sood \& Scholfield, n.d.) and difficulty in integrating with existing library automation systems (Bi, Cao \& Sheng, 2011) are barriers to RFID systems. Most libraries use RFID for a security function. RFID technology provides security through its ability to detect whether or not a book is checked-out. However, people with ill intent may exploit the non-line-of-sight operation and other weaknesses in a library's RFID system resulting in theft and loss of library material (Butters, 2007). Such threats may be addressed by employing non-tag based security as well.

\section{Economic Issues}

The deployment of RFID technology in libraries is costly (Madhusudhan, 2010; Bahri \& Ibrahim, 2013). The costs have to cover the initial hardware and software purchase, middleware and tag (Mehrjerdi, 2011), training and RFID infrastructure maintenance. Libraries with small budgets may find it difficult to start using RFID. A label costs USD 0.55 for a minimum of 100,000 pieces. With additional equipment cost, a library of this size (100,000 pieces) has to invest about USD 150,000 in total (Kern, 2004). While the cost of implementation of RFID technology in a public library is typically low because of a smaller collection size, it may incur relatively more expensive RFID tags (Butters, 2008).

Another issue is limited market opportunities for RFID technologies. Traditional approaches of handling and supporting information services are still used by most universities. The limited market opportunities for RFID technologies in information work have left university libraries lagging behind the knowledge society, sustainable development goals, and modern information practices based on current technology.

\section{Privacy Issues}

An RFID system can detect all activities or transactions performed by users using an RFID reader. However, this raises the issue of users' and staff members' privacy (Power, 2005). Because of this, some libraries have chosen not to implement an RFID system. All user activities in a library such as reading and browsing, can be easily detected by the RFID reader (Mehrjerdi, 2011). Some users may object to an RFID related system due to the perceived invasion of privacy.

\section{CRITICAL SUCCESS FACTORS}

\section{Critical Success Factors Framework}

We summarize the critical factors for successful implementation of RFID technology in libraries. We followed a generic critical success factor model that has been applied in project management problems and this model can be categorized into strategic and tactical level factors (Esteves \& Pastor, 2001). Critical success factors are strongly related to the mission and strategic goals of a business or project (European Union Agency for Network and Information Security, n.d.).

A number of researchers have studied critical success factors for RFID projects in general by using different research methodologies including case studies, site surveys and interviews. For example, (Ngai et al., 2010) presented a framework to support managers in the preliminary analysis of the suitability of RFID technologies. Seven key success factors in the 
Table 6. Critical success factors framework for RFID implementation in libraries

\begin{tabular}{l|l}
\hline Strategic Factors & Tactical Factors \\
\hline - Top management & - Starting with a small and customized \\
- Clear objective and vision & project * \\
- Project plan and timeframe & - Integration with existing IT \\
- Choosing a reliable and experienced & infrastructure * \\
vendor * & - Site survey and performance testing \\
- Consideration of privacy concerns * & - Data management * \\
& - Effective communication \\
& - Training and education * \\
\hline
\end{tabular}

development of RFID projects were identified (Fish \& Forrest, 2007). Other studies were interested in RFID projects in supply chain (Gaukler \& Seifert, 2007; Tamas \& Jozsef, 2007) and Enterprise System (Sabbaghi \& Vaidyanathan, 2008). For instance, Sabbaghi and Vaidyanathan (2008) identified three critical risk factors for implementing RFID projects in the Enterprise System - complexity of process implementation, integration and interdependency of processes, and security of processes.

Table 6 presents the common factors and barriers that influence RFID implementation. Our analysis of RFID projects found that it is important to consider factors such as strong motivation and vendor selection, the specific needs of the library, integration of RFID with existing IT infrastructure and privacy issues. The individual factors specific to RFID implementation in libraries are also discussed.

\section{Strategic Factors}

Identifying strategic issues is critical at the beginning of a project (Pinto \& Slevin, 1987). Strategies often change to solve problems dynamically and continuously. Hence, libraries need to understand why they are implementing RFID system and obtain "top to bottom" commitment of the organization. They should have a clear business vision, top management support, and plan a reasonable project timeframe (Ngai et al., 2010). Important considerations are privacy concerns (Bansode \& Desale, 2009; Ting, Tsang \& Tse, 2013), and reliable and experienced vendors (Narayanan, Singh \& Somasekharan, 2005; Bahri \& Ibrahim, 2013).

\section{Consideration of privacy concerns}

This factor is critical because it concerns user privacy. An RFID reader is able to detect and identify all transactions or activities performed by users (Bansode \& Desale, 2009). This is similar to surveillance. Consequently, users are likely to become worried about their privacy and may be reluctant to use such services. There is also the possibility of unauthorized users intercepting communications between the tags and RFID reader (Ting, Tsang \& Tse, 2013). Users may not wish to share their personal information without prior consent. To address concerns related to privacy, the library should provide training for users on basic RFID knowledge, its benefits and how the library users' data are protected. 


\section{Choosing a reliable and experienced vendor}

Many RFID vendors in the market claim to be able to provide RFID solution for libraries, but their reliability and real experience are doubtful. The success of RFID implementation in the library depends on the selection of a reliable and experienced RFID solutions provider. (Narayanan, Singh \& Somasekharan, 2005). Important considerations to bear in mind when evaluating different vendors include the security features, tag memory capacity and tag functionality. The selection of a suitable and experienced vendor is crucial as it is an emerging technology (Bahri \& Ibrahim, 2013). If a library selects a vendor which is unable to customize the technology it supplies to current or existing technology in the library, operations will be impeded.

\section{Tactical Factors}

This section will focus on tactical factors in the development of RFID technology in the library. Different researchers have their own theories. Libraries should start with a small or customized project (Madhusudhan, 2010; Suda \& Rani, 2013; Repanovici \& Cristea, 2011), provide staff training and education (Bansode \& Desale, 2009), and integrate RFID with existing IT infrastructure (Coyle, 2005; Singh \& Midha, 2008). In addition, performance testing and data integration (Butters, 2008; Chelliah, Sood \& Scholfield, n.d.) are critical in ensuring the performance and compliance of RFID systems.

\section{Starting with a small or customized project}

RFID technology must be customized to suit the needs and structure of the library (Suda \& Rani, 2013). For example, the University of Hong Kong's library has installed EasyCheck units, EasyReturn units and EasyDetect units to ensure better adaptation and continues to refine the process. The risk of failure can be reduced by starting with a small project.

In Delhi, the implementation of RFID technology is still slow and few libraries have adopted the technology (Madhusudhan, 2010). From the data collection and surveys, many libraries are either in the process of implementation or planning to implement RFID technology. Meanwhile, in Transylvania University, RFID technology is integrated with the Koha open source system to achieve an economical solution with large capability (Repanovici \& Cristea, 2011). Reasons for starting with a small RFID project are that it offers better agility and can be easily modified to accommodate changes. The success of small RFID projects in turn pave the way for the implementation of RFID technology in larger projects.

\section{Staff training and education}

RFID is a relatively new technology and library staff may not have either prior knowledge of it or the necessary skills related to its use. Hence, the lack of any technological experts in the library is a problem when implementing RFID technology (Bansode \& Desale, 2009). The lack of training and skill affects the use of RFID technology (Cunningham, 2010). This situation causes problems on a daily basis. In order to overcome this problem, the provision of training and education to develop library staff's competence in using RFID technology is essential.

\section{Integration with existing IT infrastructure}

When integrating RFID technology with existing library systems, it is important that the library links it to the appropriate devices or tools. Doing so ensures that integration is cost- 
effective and efficient. Using the appropriate resources (i.e. existing hardware and software) can reduce costs and effort when integrating RFID with the existing systems, such as integrating RFID technology with PDA or mobile devices in libraries to perform the library's daily operations (Satpathy \& Mathew, 2006). An important factor for implementing RFID is its ability to integrate with existing technology and applications (Verma \& Garg, 2014). Successful implementation of RFID depends on efficient performance (i.e. it is faster as compared to barcode technology), compatibility, and proper integration. Proper integration between RFID technology and existing IT infrastructure will then lead to data integrity and system compliance.

\section{Data management}

The implementation of RFID technology enhances the efficiency and effectiveness of data management in libraries. At the University of Hong Kong, implementation of RFID technology automates library management and is very efficient for data management (Suda \& Rani, 2013). There are two methods to handle transaction data in the form of an RFID tag (Yu, 2008). The first method is to record data within the tag. The second method is to record the information in the database system. These two data management methods can help libraries manage their data properly and efficiently.

Table 7 lists the case studies which were analyzed to identify critical success factors, and indicates which factors were important to the project outcome of each case.

C1: City-U HK Library System, C2: Jayakar Library, Pune Library, C3: Kenyan University Libraries, C4: Transylvania University (Library system integrated with RFID). Strategic factors were analyzed at the project planning stage. Based on Table 7, support from top management is important to the success of RFID project in libraries. C1, C2 and C3 considered this factor but not C4. The roles of top management were emphasized in most cases. Senior management and technical staff were involved in the project and they devoted appropriate time to allocate resources to the implementation efforts. In the market, RFID components vary across vendors. In choosing technology vendors, libraries prefer to partner big companies or libraries that have experience in RFID projects and are familiar with RFID services. In the cases we reviewed, C1, C2, C3 and C4 considered the selection of a reliable and experienced vendor. Other important considerations are a clear strategy and mission. In our studies, C1, C2, C3 and C4 also identified this as a key contribution to success when implementing the RFID project. We observe that the project plan and time frame are not mentioned in the literature although they are traditional critical success factors for project management. Privacy is another major concern in the implementation of an RFID project in the library. But only C1 considered this while the others ignored this factor.

Tactical factors are considered at the action phase. All of the organizations started with relatively small and customized projects. This is important, to ensure that small projects can support all the requirements before customization begins and the RFID system is rolled out for all the library's transactions and operations. Table 7 also indicates how RFID data were integrated with existing IT infrastructure. For instance, any standalone application in the library can be integrated with the RFID system in terms of data transmission, along with other considerations. Only case C2 did not consider this. Another consideration is site survey and performance testing. Only case C3 did not consider this. The purpose is to evaluate the performance of RFID technology based on previous or current RFID projects in different domains or areas before its adoption in libraries. Cases C1, C2 and C4 applied this tactical factor before implementing RFID technology in libraries. None of the case studies mentioned 
Table 7. Case studies of critical success factors

\begin{tabular}{|c|c|c|c|c|c|}
\hline \multicolumn{2}{|c|}{ Critical success factor } & \multicolumn{4}{|c|}{ Case studies } \\
\hline Strategic & Top management support & \multirow{2}{*}{$\begin{array}{c}\text { C1 } \\
\text { (Ching \& } \\
\text { Tai, 2009) } \\
\text { X } \\
\text { X }\end{array}$} & $\begin{array}{c}\text { C2 } \\
\text { (Bansode \& } \\
\text { Desale, 2009) } \\
\mathrm{X}\end{array}$ & $\begin{array}{c}\text { C3 } \\
\text { (Makori, } \\
\text { 2013) } \\
X\end{array}$ & $\begin{array}{c}\text { C4 } \\
\text { (Repanovici \& } \\
\text { Cristea, 2011) } \\
-\end{array}$ \\
\hline & $\begin{array}{l}\text { Choosing a reliable and } \\
\text { experienced vendor }\end{array}$ & & $\mathrm{X}$ & $\mathrm{X}$ & $\mathrm{X}$ \\
\hline & $\begin{array}{l}\text { A clear RFID strategy and } \\
\text { vision }\end{array}$ & $\mathrm{X}$ & $\mathrm{X}$ & $\mathrm{X}$ & $\mathrm{X}$ \\
\hline & Project plan and time frame & - & - & - & - \\
\hline & $\begin{array}{l}\text { Considerations and privacy } \\
\text { concerns }\end{array}$ & $\mathrm{X}$ & - & - & - \\
\hline \multirow[t]{6}{*}{ Tactical } & $\begin{array}{l}\text { Starting with a small and } \\
\text { customized project }\end{array}$ & $\mathrm{X}$ & $\mathrm{X}$ & $\mathrm{X}$ & $\mathrm{X}$ \\
\hline & $\begin{array}{l}\text { Integration with existing IT } \\
\text { infrastructure }\end{array}$ & $\mathrm{X}$ & - & $\mathrm{X}$ & $\mathrm{X}$ \\
\hline & $\begin{array}{l}\text { Site survey and performance } \\
\text { testing }\end{array}$ & $\mathrm{X}$ & $\mathrm{X}$ & - & $\mathrm{X}$ \\
\hline & $\begin{array}{l}\text { Data integration and } \\
\text { management }\end{array}$ & - & - & - & - \\
\hline & Effective communication & - & - & - & - \\
\hline & Training and education & - & $\mathrm{X}$ & - & $\mathrm{X}$ \\
\hline
\end{tabular}

data integration and management, and effective communication, although they were reported as major barriers in the literature. Finally, staff training was mentioned in cases C1 and C3.

\section{Implications for Practitioners}

Our critical success factors framework can guide librarian stakeholders towards a successful implementation of RFID projects. They should prepare and conduct an extensive assessment of the benefits and barriers of implementing RFID systems in their own organizations and assess their capability to overcome the barriers. If they decide to implement RFID technology, they must examine each strategic and tactical factor based on our proposed critical success factors framework. We provide the following guidelines:

1. The stakeholders should perform a sound projection of the project's return on investment (ROI) before implementing an RFID project. Cost is one of the major factors influencing the acceptance of RFID technology. Although the production cost of RFID has been reduced and Alien Technology, a leading supplier of RFID technology, has cut the price of the tag to less than USD 0.20, the retail price is still prohibitive. For instance, libraries with collections of over 100,000 items will have to shoulder a huge financial burden when adopting RFID. The cost savings for libraries stem from workflow optimization, human error reduction, improvement of service quality and reduced circulation time. Library users' satisfaction and staff productivity should also be evaluated. 
2. Technology vendors should also customize RFID systems for libraries and make them interoperable with existing library computer systems since the requirements for each library can vary with factors such as its size or user population. In order to reduce cost, barcodes and existing wireless networks can be combined with RFID technology. In future, RFID system should be designed with the capability of modifying and removing services.

3. Integration with existing IT infrastructure in library is another factor that must be considered in the implementation of RFID technology. RFID systems must be able to comply with existing IT infrastructure in order to reduce the cost of implementation such as the cost of upgrading or purchase of new IT infrastructure to support RFID systems. For instance, to counter prohibitive costs, substitute RFID-designed reader networks with an existing Wi-Fi network.

4. Privacy is also a subject of debate in the application of RFID technology. All user activities such as book reading, borrowing, returning and searching will be detected by readers installed in libraries. In order to overcome this challenge, all users must be educated on the usefulness and advantages of RFID in comparison to previous technology used in the library, such as barcode.

Library users and staff should be educated about RFID technology so they can have a better understanding of the benefits and privacy issues. Once they realize that RFID technology can improve data security and reduce transaction errors, they will be more inclined to use RFID technology.

\section{CONCLUSION}

Various benefits of RFID applications have been identified. RFID technology supports tracking of library materials, reduces threats to the library collection, improves accuracy of data collection, and reduces the amount of time required to perform the circulation operations of check-in, check-out, inventory control and shelf-management. Information can be read from RFID tags more quickly than from bar codes and several items in a stack can be read at the same time. RFID systems also have a security function to detect theft. RFID technology is revolutionizing library operations and services.

The library also presents unique challenges for RFID adoption, including technological constraints, cost concerns and privacy concerns. Hence, researchers in different fields should leverage their expertise to address these challenges, including the high cost of development of an RFID project, market degeneration and unnecessary development, and the development of an international standard. When addressing technological issues, researchers should combine the library management system and RFID system to achieve precise positioning of books, self-checkout, efficiency of inventory control and arrangement, anti-theft and other functions. Privacy is a subject of contention as all activities performed by users can be detected easily by RFID readers. Legal issues concerning users' consent to data tracking also need to be addressed. Libraries would be more inclined to adopt RFID technology if such concerns are addressed through advancements in technology and legislation safeguarding user privacy.

\section{REFERENCES}

Abdou, M. S. (2012). RFID in the Egyptian libraries: Case study. Paper presented at the 5th. Wildauer Bibliotheks-Symposium "RFID and Beyond", September 2012. Wildau, Germany: Technical University of Applied Sciences. Retrieved from https://www.thwildau.de/fileadmin/dokumente/bibliothek/dokumente/Rfid_2012_Vortraege/RFIDinE 
gypt.pdf

Addepalli, S. L., \& Addepalli, S. G. (2014). Library management system using RFID technology. International Journal of Computer Science and Information Technologies, 5(6), 6932-6935.

Ansari, M. S., \& Khatri, N. G. (2011). Automated RFID based library management systems, Paper presented at the Symposium on Information \& Computer Sciences (ICS 2011) (pp. 5-8). Retrieved from http://eprints.sunway.edu.my/93/1/ICS2011_02.pdf

Bahri, S., \& Ibrahim, A. (2013). RFID in libraries: A case study on implementation. Library Hi Tech News, 30(5), 21-26. Retrieved from http://doi.org/10.1108/LHTN-03-20130012

Bansode, S. Y., \& Desale, S. K. (2009). Implementation of RFID technology in University of Pune Library. Program: Electronic Library and Information Systems, 43(2), 202-214. Retrieved from http://doi.org/10.1108/00330330910954406

Bi, C., Cao, J., \& Sheng, X. (2011). Radio frequency identification technology and its application in the library. In International Conference on Information Computing and Applications (pp. 646-651). Berlin: Springer.

Blansit, B. D. (2010). RFID terminology and technology: Preparing to evaluate RFID for your library. Journal of Electronic Resources in Medical Libraries, 7(4), 344-354. Retrieved from http://doi.org/10.1080/15424065.2010.527255

Boss, R. W. (2003). RFID technology for libraries. Library Technology Reports, 39(6), 1-19. Retrieved from http://staging.ala.org/ala/mgrps/divs/pla/plapublications/platechnotes/RFID-2007.pdf

Butters, A. (2007). RFID systems, standards and privacy within libraries. The Electronic Library, 25(4), 430-439. Retrieved from http://doi.org/10.1108/02640470710779844

Butters, A. (2008). RFID in Australian academic libraries: Exploring the barriers to implementation. Australian Academic \& Research Libraries, 39(3), 198-206. Retrieved from http://doi.org/10.1080/00048623.2008.10721350

Cadoo, S. (2004). RFID use within libraries: an Australian perspective. Retrieved from https://www.yumpu.com/pt/document/view/17437706/rfid-use-within-libraries-anaustralian-perspective-alia-conferences

Caldwell-Stone, D. (2010). RFID in libraries. Library Technology Reports, 46(8), 38-44. Retrieved from http://alatechsource.metapress.com/content/L6K6808340437M66\n

Chelliah, J., Sood, S., \& Scholfield, S. (2015). Realising the strategic value of RFID in academic libraries: A case study of the University of Technology Sydney. The Australian Library Journal, 64(2), 113-127. Retrieved from http://doi.org/10.1080/00049670.2015.1013005

Ching, S. H., \& Tai, A. (2009). HF RFID versus UHF RFID: Technology for library service transformation at City University of Hong Kong. Journal of Academic Librarianship, 35(4), 347-359. Retrieved from http://doi.org/10.1016/j.acalib.2009.04.005

Condos, E., \& Ginther, C. (2011). Radio-Frequency Identification (RFID) plan. Retrieved from https://biblioottawalibrary.ca/sites/default/files/Board_Docs/111017/Doc\%209\%20\%20 RFID\%20Plan\%20October\%2017\%202011.pdf

Coyle, K. (2005). Management of RFID in libraries. The Journal of Academic Librarianship, 31(5), 486-489. Retrieved from http://doi.org/10.1016/j.acalib.2005.06.001

Cunningham, M. S. (2010). A case study into the implementation of RFID at the Pilkington Library Loughborough University. Loughborough University Institutional Repository.

Curran, K., \& Porter, M. (2007). A primer on radio frequency identification for libraries. 
Library Hi Tech, 25(4), 595-611. Retrieved from http://doi.org/10.1108/07378830710840536

Dhanalakshmi, M., \& Mamatha, U. (2009). RFID based library management system. In Proceedings of ASCNT 2009, CDAC, Noida, India, 19(55), 227-234.

Dwivedi, Y. K., Kaur, K., Williams, M. D., \& Williams, J. (2013). RFID systems in libraries: An empirical examination of factors affecting system use and user satisfaction. International Journal of Information Management, 33(2), 367-377. Retrieved from http://doi.org/10.1016/j.ijinfomgt.2012.10.008

Engel, E. (2006). RFID implementations in California libraries : Costs and benefits. US Institute of Museum and Library Services.

Esteves, J., \& Pastor, J. (2001). Analysis of critical success factors relevance along SAP implementation phases. In Seventh Americas Conference on Information Systems (pp. 1019-1025).

European Union Agency for Network and Information Security (n.d.) Critical success factors. Retrieved from https://www.enisa.europa.eu/topics/threat-risk-management/riskmanagement/current-risk/risk-management-inventory/rm-isms/critical-success-factors

Evans, C., \& Moore, A. (2013). Using RFID technology at University of Sussex. SCONUL Focus, 59, 13-15. Retrieved from http://www.sconul.ac.uk/sites/default/files/documents/5_12.pdf

Feng, C. (2010). Research for application of RFID in library. In 2010 International Conference on Computer and Communication Technologies in Agriculture Engineering (CCTAE) (pp. 262-264). Retrieved from http://doi.org/10.1109/CCTAE.2010.5544208

Fennani, A., \& Hamam, H. (2008). An optimized RFID-based academic library. In Second International Conference on Sensor Technologies and Applications (Sensorcomm 2008) (pp. 44-48). Retrieved from http://doi.org/10.1109/SENSORCOMM.2008.63

Fish, B. L. A., \& Forrest, W. C. (2007). The 7 Success Factors of RFID. Supply Chain Management Review, 10(6).

Fujisaki, K. (2015). Implementation of a RFID-based System for library management. International Journal of Distributed Systems and Technologies, 6(3). Retrieved from http://doi.org/10.4018/IJDST.2015070101

Gaukler, G. M., \& Seifert, R. W. (2007). Applications of RFID in supply chains. In Trends in supply chain design and management (pp. 29-48). Springer London.

Howard, L., \& Anderson, M. (2005). RFID technology in the library environment. Journal of Access Services, 3(2), 29-39. Retrieved from http://doi.org/10.1300/J204v03n02_03

Huang, X. (2012). Application practice and analysis research of RFID technology in digital library. In International Symposium on Information Technology in Medicine and Education (pp. 473-475). Retrieved from http://doi.org/978-1-4673-2108-2112

Jain, A. A. K., \& Krishna, T. R. (2014). Dynamic book search using RFID technology. International Journal of Engineering Research and General Science, 2(6), 138-142.

Kapoor, K., Dwivedi, Y. K., Piercy, N., \& Lal, B. (2014). RFID integrated systems in libraries: Extending TAM model for empirically examining the use. Journal of Enterprise Information Management, 27(6), 1-23. Retrieved from http://doi.org/10.1108/JEIM-10-2013-0079

Kern, C. (2004). Radio frequency identification for security and media circulation in libraries. The Electronic Library, 22(4), 317-324. Retrieved from http://doi.org/10.1108/02640470410552947

Kotecha, D. H. (2008). Automation in library using RFID technology. Retrieved from http://ir.inflibnet.ac.in/handle/1944/1106 
Li, L. (2013, December). Designing and implementation of university library automatic management system based on the Internet of Things. In Joint International Conference on Pervasive Computing and the Networked World (pp. 241-247). Springer International Publishing.

Library Book/Media Management and RFID Tracking. (n.d.). Bradford Systems. Retrieved from http://www.bradfordsystems.com/files/docs/library.pdf

Liu, C. M., \& Chen, L.S (2009). Applications of RFID technology for improving production efficiency in an integrated-circuit packaging house. International Journal of Production Research, 47(8), 2203-2216. Retrieved from http://doi.org/10.1080/00207540802380556

Madhusudhan, M. (2010). RFID technology implementation in two libraries in New Delhi. Program: Electronic Library and Information Systems, 44(2), 149-157. Retrieved from http://doi.org/10.1108/00330331011039508

Makori, E. O. (2013). Adoption of radio frequency identification technology in university libraries: A Kenyan perspective. The Electronic Library, 31(2), 208-216. Retrieved from http://doi.org/10.1108/02640471311312384

Mamdapur, G. M. N., \& Rajgoli, I. U. (2011). Implementing radio frequency identification technology in libraries: Advantages and disadvantages. International Journal of Library and Information Science, 3(3), 46-57. Retrieved from http://www.researchgate.net/profile/Ghouse_Modin_Mamdapur/publication/235698057 _Implementing_radio_frequency_identification_technology_in_libraries_Advantages_a nd_disadvantages/links/0912f512b268c2ec91000000.pdf

Markakis, I., Samaras, T., Polycarpou, A. C., \& Sahalos, J. N. (2013). An RFID-enabled library management system using low-SAR smart bookshelves. In 2013 International Conference on Electromagnetics in Advanced Applications (ICEAA) (pp. 227-230). Retrieved from http://doi.org/10.1109/ICEAA.2013.6632228

Mehrjerdi, Y. Z. (2011). RFID: The big player in the libraries of the future. The Electronic Library, 29(1), 36-51. Retrieved from http://doi.org/10.1108/02640471111111424

Mendeley. (2010). Mendeley Desktop. Retrieved from http://doi.org/10.1378/chest.122.6.2183

Minami, T. (2006). RFID tag based library marketing for improving patron services. In Pacific Rim Knowledge Acquisition Workshop (PKAW 2006), Guilin, China, August 7-8, 2006 (pp. 51-63). Berlin: Springer. Retrieved from http://link.springer.com/chapter/10.1007/11961239_5

Mohideen, Z. A., Muhamad, S., Ghadzali, M. P., \& Mohd Arshad, M. R. (2012). A practical approach to radio frequency identification library management system. In 2012 IEEE International Conference on RFID-Technologies and Applications (RFID-TA) (pp. 323-329). Retrieved from http://doi.org/10.1109/RFID-TA.2012.6404539

Narayanan, A., Singh, S., \& Somasekharan, M. (2005). Implementing RFID in library: Methodologies, advantages and disadvantages. In Proceedings of the Conference on Recent Advances in Information Technology (pp. 271-281). Madras Library Association-Kalpakkam Chapter, and Indira Gandhi Centre for Atomic Research, Kalpakkam.

Ngai, E. W. T., To, C. K. M., Moon, K. K. L., Chan, L. K., Yeung, P. K. W., \& Lee, M. C. M. (2010). RFID systems implementation: A comprehensive framework and a case study. International Journal of Production Research, 48(9), 2583-2612. Retrieved from http://doi.org/10.1080/00207540903564942

Pinto, J. K., \& Slevin, D. P. (1987). Critical factors in successful project implementation. 
IEEE Transactions on Engineering Management, EM-34(1), 22-27.

Potdar, V., Wu, C., \& Chang, E. (2010). Automated data capture technologies: RFID. In J. Symonds (Ed.), Ubiquitous and pervasive computing: Concepts, methodologies, tools, and applications (pp 82-111). Hershey, PA: IGI-Global.

Power, J. L. (2005). RFID and libraries. Journal of Access Services, 3(2), 83-87. Retrieved from http://doi.org/10.1300/J204v03n02

Rafiq, M. (2004). Radio frequency identification (RFID): Its usage and libraries. Retrieved from http://eprints.rclis.org/6179/

Rajasekar, V., Dhanakar, M. A., Pandian, R., \& Malliga, R. (2008). RFID technology in Anna University Library Management: A study. Retrieved from http://ir.inflibnet.ac.in/handle/1944/1129

Ramanathan, R., Ramanathan, U., Wan, L., \& Ko, L. (2014). Adoption of RFID technologies in UK logistics: Moderating roles of size, barcode experience and government support. Expert Systems With Applications, 41(1), 230-236. Retrieved from http://doi.org/10.1016/j.eswa.2013.07.024

Repanovici, A., \& Cristea, L. (2011). RFID technology used in small library-case study at Transilvania University. Romanian Review Precision Mechanics, Optics \& Mechatronics, 39, 109-112.

Roberts, C. M. (2006). Radio frequency identification (RFID). Computers \& Security, 25(1), 18-26. Retrieved from http://doi.org/10.1016/j.cose.2005.12.003

Sabbaghi, A., \& Vaidyanathan, G. (2008). Effectiveness and efficiency of RFID technology in supply chain management: Strategic values and challenges. Journal of Theoretical and Applied Electronic Commerce Research, 3(2), 71-81. Retrieved from http://doi.org/10.4067/S0718-18762008000100007

Sahin, I. (2006). Detailed review of Rogers' diffusion of innovations theory and educational technology: Related studies based on Rogers' theory. The Turkish Online Journal of Educational Technology, 5(2), 14-23.

Satoglu, S. I., Ustundag, A., \& Kilinc, M. S. (2013). The value of RFID in library management system. In A. Ustundag(Ed.), The value of RFID: Benefits vs. costs (pp. 155-167). London: Springer. Retrieved from http://link.springer.com/chapter/10.1007/978-1-4471-4345-1_12

Satpathy, L., \& Mathew, A. P. (2006). RFID assistance system for faster book search in public libraries. Proceedings of ACM CHI 2006 Conference on Human Factors in Computing Systems, 2, 1289-1294. Retrieved from http://doi.org/10.1145/1125451.1125691

Schneider, K. G. (2003). RFID and libraries: Both sides of the chip. Retrieved from http://www.ala.org/offices/sites/ala.org.offices/files/content/oif/ifissues/rfidbothsidesch ip.pdf

Shahid, S. M. (2005). Use of RFID technology in libraries: A new approach to circulation, tracking, inventorying, and security of library materials. Library Philosophy and Practice. Retrieved from http://digitalcommons.unl.edu/libphilprac/62/

Singh, G., \& Midha, M. (2008). RFID: A new technology in library management systems. Journal of Interlibrary Loan Document Delivery Electronic Reserve, 18(4), 439-447. Retrieved from http://doi.org/10.1080/10723030802181778

Singh, N. K., \& Mahajan, P. (2014). Application of RFID technology in libraries. International Journal of Library and Information Studies, 4(2), 1-9.

Suda, K., \& Rani, N. (2013). Radio frequency identification for efficient library management. Ijbssnet.Com, 4(15), 125-131. Retrieved from 
http://ijbssnet.com/journals/Vol_4_No_15_Special_Issue_November_2013/18.pdf

Sumi, S., \& Kumar, J. (2007). Application of RFID technology in libraries. Paper presented at the 5th International CALIBER -2007, Panjab University, Chandigarh, 08-10 February, 2007. Retrieved from http://ir.inflibnet.ac.in/bitstream/1944/1422/1/459467.pdf

Tamas, H., \& Jozsef, M. (2007). RFID applications in the supply chain. In 1st Annual RFID Eurasia, 2007. Retrieved from http://doi.org/10.1109/RFIDEURASIA.2007.4368132

Ting, S. L., Tsang, A. H. C., \& Tse, Y. K. (2013). A framework for the implementation of RFID systems. International Journal of Engineering Business Management, 5, 9. Retrieved from http://doi.org/10.5772/56511

Verma, A., \& Garg, N. (2014). RFID library implementation. International Journal of Computer Science and Mobile Computing, 3(4), 761-764.

Vimalraj, S., \& Sameera, S. S. (2015). RFID based library management system. International Journal of Innovative Research in Advanced Engineering, 2(1), 326-329.

Viziteu, G., Florean, B., Moraru, G. M., \& Pintea, A. (2012). An overview of RFID technology used in library. In 2012 International Conference and Exposition on Electrical and Power Engineering (pp. 108-111). IEEE. Retrieved from https://www.infona.pl/resource/bwmeta1.element.ieee-art-000006463614

Yu, S.-C. (2007). RFID implementation and benefits in libraries. The Electronic Library, 25(1), 54-64. Retrieved from http://doi.org/10.1108/02640470710729119

Yu, S.-C. (2008). Implementation of an innovative RFID application in libraries. Library Hi Tech, 26(3), 398-410. Retrieved from http://doi.org/10.1108/07378830810903328

Zhang, D., \& Shi, X. (2011). Self-service management platform design for library based on RFID. In 2nd International Conference on Artificial Intelligence, Management Science and Electronic Commerce, AIMSEC 2011 - Proceedings (pp. 7237-7240.) Retrieved from http://doi.org/10.1109/AIMSEC.2011.6010604 